Jurnal Kesehatan Perintis (Perintis's Health Journal) 8 (1) 2021: 82-90

Contents list available at JKP website

Jurnal Kesehatan Perintis (Perintis's Health Journal)

Journal homepage: https://jurnal.stikesperintis.ac.id/index.php/JKP

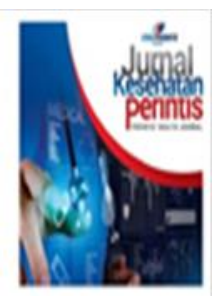

\title{
Pemeriksaan GeneXpert Terhadap Tingkat Positivitas Pemeriksaan Basil Tahan Asam (BTA) Metode Ziehl Neelsen Pada Penderita Suspek TB Paru
}

\author{
Putra Rahmadea Utami ${ }^{1,}$ Nurul Amelia ${ }^{1,}$ Vetra Susanto", Tika Dwita Adfar ${ }^{2}$ \\ ${ }^{1)}$ Progam Studi D-III TLM, Universitas Perintis Indonesia, Sumatera Barat, Indonesia \\ ${ }^{2)}$ Program Studi Gizi, Universitas Perintis Indonesia, Sumatera Barat Indonesia
}

\section{Article Information :}

Submission: May 05, 2021; Revised:Jun 26, 2021; Accepted:Jun 30, 2021; Available online: Jun 30,2021

*Corresponding author : putrarahmadeautami@upertis.ac.id

\begin{abstract}
ABSTRAK
Tuberkulosis (TB) merupakan penyakit infeksi bakteri menahun yang disebabkan oleh Mycobacterium tuberkulosis, suatu basil tahan asam yang ditularkan melalui udara. Tujuan penelitian ini Untuk mengetahui hubungan hasil pemeriksaan GeneXpert dengan tingkat positivitas pemeriksaan BTA Metode Ziehl Neelsen pada penderita Suspek TB Paru. Jenis penelitian ini merupakan penelitian analitik observasi desain cross sectional. Hasil Penelitian penderita Suspek TB Paru sebanyak 190 sampel dengan jenis kelamin laki-laki sebanyak 97 sampel (51,1\%) dan perempuan sebanyak 93 sampel (48,9\%), Hasil pemeriksaan GeneXpert pada penderita Suspek TB Paru didapatkan hasil pada metode GeneXpert, MTB Not Detection sebanyak 147 orang, MTB Detection Low sebanyak 20 orang, MTB Detection Medium sebanyak 17 orang, MTB Detection High sebanyak 6 orang. Tingkat Positivitas hasil pemeriksaan BTA Metode Ziehl Neelsen metode Ziehl Neelsen didapatkan hasil negatif sebanyak 147 orang, hasil positif Satu (1+) sebanyak 20 orang, hasil positif Dua (2+) sebanyak 17 orang dan hasil positif Tiga (3+) sebanyak 6 orang. Terdapat hubungan yang bermakna antara metode GeneXpert dengan BTA metode Ziehl Neelsen yang mana nilai significance $<0,05$ yaitu 0,00 .
\end{abstract}

Kata kunci : tuberkulosis, genexpert, ziehl neelsen, BTA, mycobacterium tuberkulosis

\section{ABSTRACT}

Tuberculosis (TB) is a chronic bacterial infection caused by Mycobacterium tuberculosis, an acid-resistant bacteria that is transmitted through the air. The purpose of this study was to determine the correlation between the results of the GeneXpert examination and the positivity level of the Ziehl Neelsen BTA examination in patients with pulmonary TB suspension. This type of research is an observational analytic study with cross sectional design. The results of the study of patients with Suspect Pulmonary TB 190 samples were 97 samples (51.1\%) male and 93 samples (48.9\%) female. 147 people, MTB Detection Low 20 people, MTB Detection Medium 17 people, MTB Detection High 6 people. Positivity level of the results of the AFB examination of the Ziehl Neelsen Method of the Ziehl Neelsen method obtained 147 negative results, 20 positive results of One (1+), 17 positive results of Two (2+) and 6 positive results of Three $(3+)$. Research Results There was a significant relationship 
between the GeneXpert method and the Ziehl Neelsen BTA method where the significance value was $<0.05$, namely 0.00 .

Keyword: tuberculosis, genexpert, ziehl neelsen, BTA, Mycobacterium tuberculosis

\section{PENDAHULUAN}

Tuberkulosis (TB) merupakan penyakit infeksi bakteri menahun yang disebabkan oleh Mycobacterium tuberkulosis, suatu basil tahan asam yang ditularkan melalui udara. Tuberkulosis dapat menyebar dari satu orang ke orang lain melalui transmisi udara (droplet dahak pasien penderita tuberkulosis). Pasien yang terinfeksi Tuberkulosis akan memproduksi droplet yang mangandung sejumlah basil tahan asam Mycobacterium tuberkulosis ketika mereka batuk, bersin, atau berbicara. Orang yang menghirup basil tahan asam TB tersebut dapat terinfeksi Tuberkulosis. Bersama dengan malaria dan HIV/AIDS, TB paru menjadi salah satu penyakit yang pengendaliannya menjadi komitmen global dalam MDG's. Penyakit TB paru bila tidak ditangani dengan benar akan menimbulkan komplikasi seperti pleuritis, efusi pleura, laryngitis, dan TB usus (Susanti, 2013)

Menurut WHO dalam Global Tuberkulosis Report 2018, TB merupakan salah satu penyakit dari 10 penyebab kematian di dunia. TB juga merupakan penyebab utama kematian yang berkaitan dengan antimicrobial resestence dan pembunuh utama penderita HIV. Pada tahun 2017, diperkirakan terdapat 10,4 juta kasus baru (insidensi) TB di seluruh dunia, diantaranya 6,2 juta laki-laki, 3,2 juta wanita, dan 1 juta adalah anak-anak. Dan diantara penderita TB tersebut, 10\% diantaranya merupakan penderita HIV positif. 7 negara yang menyumbang $64 \%$ kasus baru TB di dunia adalah India, Indonesia, Tiongkok, Filipina, Pakistan,Nigeria, dan Afrika Selatan. Pada tahun yang sama, 1,7 juta orang meninggal karena TB termasuk didalamnya 0,4 juta merupakan penderita HIV. Namun secara global, tingkat kematian penderita TB mengalami penurunan sebanyak $37 \%$ dari tahun 2000-2018 (Kurniawan et al., 2016).

Diagnosis TB paru dengan metode mikroskopis Basil Tahan Asam (BTA) menggunakan spesimen dahak. Salah satu faktor yang menentukan keberhasilan diagnosis TB paru dengan metode mikroskopis Basil Tahan Asam (BTA) adalah penanganan spesimen dahak. Idealnya spesimen dahak harus segera diperiksa. Jika karena suatu hal sehingga spesimen dahak tidak dapat segera diperiksa, maka biasanya spesimen disimpan ditempat dingin dengan harapan tidak mengalami perubahan dan menghindarkan dari serangga misalnya di dalam lemari pendingin.Tidak dianjurkan membiarkan spesimen dahak pada suhu ruangan. Masa penyimpanan dahak dapat dipertimbangkan sama seperti penyimpanan susu (Muin et al., 2020).

Di Indonesia merupakan salah satu negara berkembang dengan jumlah penyakit infeksi TB yang tinggi di dunia, maka sangat diperlukan diagnosis dan pengobatan yang cepat dan tepat sehingga dapat menekan penularannya. Mengingat cukup banyaknya kasus Basil Tahan Asam (BTA) negatif pada pasien yang diduga menderita tuberkulosis, maka sangat diperlukan pemeriksaan diagnostik yang cepat untuk membuktikan ada tidaknya bakteri Mycobacterium tuberkulosis tersebut. Pemeriksaan mikroskopis Basil Tahan Asam (BTA) dari sputum memegang peran dalam mendiagnosis awal dan pemantauan pengobatan tuberkulosis paru. Rangkaian kegiatan yang baik diperlukan untuk mendapatkan hasil yang akurat, mulai dari cara pengumpulan sputum, pemilihan bahan.sputum yang akan diperiksa dan pengolahan sediaan dibawah mikroskop. Teknik pewarnaan yang digunakan adalah Ziehl Neelsen yang dapat mendeteksi Basil Tahan Asam (BTA) dengan menggunakan mikroskop. Keterbatasan dari teknik atau metode diagnostik saat ini merupakan salah satu hambatan dalam meningkatkan penemuan kasus TB Paru (Kurniawan et al., 2016)(Muin et al., 2020)

GeneXpert merupakan perkembangan dari teknologi saat ini yang dapat dengan 
cepat mengidentifikasi keberadaan Mycobacterium tuberkulosis dan resistensi terhadap rifampisin secara simultan, sehingga inisiasi dini terapi yang akurat dapat diberikan dan dapat mengurangi insiden TB secara umum. Kelebihan utama dari GeneXpert ini adalah hasil pemeriksaan dapat diketahui secara cepat yaitu dalam waktu 2 jam. Alat ini cocok untuk daerah endemis dan dapat dilakukan walaupun sampel sputum hanya $1 \mathrm{ml}$. Pemeriksaan GeneXpert mampu mendeteksi DNA MTB kompleks secara kualitatif dari spesimen langsung, baik dari dahak maupun non dahak juga dapat mendeteksi mutasi pada gen rpoB yang menyebabkan resistansi terhadap rifampisin. Pemeriksaan GeneXpert dapat mendiagnosis TB dan resistansi terhadap rifampisin secara cepat dan akurat (Saeed et al., 2017).

Kelemahan dari metode GeneXpert adalah metode yang digunakan terlalu kompleks untuk pemeriksaan rutin di Negara-negara berkembang serta biaya alat yang mahal. Tahapan pengolahan spesimen dan ekstraksi DNA mempersulit implementasi di Negara dengan sumber daya terbatas. Hasil negatif tidak menyingkirkan kemungkinan TB oleh karena itu pemeriksaan tersebut harus sejalan dengan pemeriksaan biakan Mycobacterium tuberkulosis untuk menghindari resiko hasil negatif palsu dan untuk mendapatkan isolat Mycobacterium tuberkulosis sebagai bahan identifikasi dan uji kepekaan (Kurniawan et al., 2016) (Saeed et al., 2017) .

Berdasarkan penelitian yang dilakukan oleh Kurniawan tentang nilai diagnostik metode "Real Time" PCR GeneXpert pada pasien TB paru BTA negatif didapatkan hasil pemeriksaan dimana dari 40 sampel sputum pasien BTA negatif didapatkan sebanyak 16 orang (40\%) yang hasil metode RT PCR GeneXpert yang positif dan negatif sebanyak 24 orang $(60 \%)$ serta tidak didapatkan adanya resistensi rifampisin (Cekin et al., 2013). Beda penelitian ini dengan penelitian-penelitian sebelumnya adalah peneliti ingin membedakan Hasil Pemeriksaan GeneXpert Dengan Tingkat Positivitas Pemeriksaan BTA Metode Ziehl Neelsen. Sedangkan penelitian oleh Kurniawan, hanya meneliti tentang perbedaan hasil teknik BTA dengan GeneXpert pada penderita TB Paru. Tujuan penelitian ini untuk mengetahui hubungan hasil pemeriksaan GeneXpert dengan tingkat positivitas pemeriksaan BTA metodezZiehl neelsen pada penderita TB paru.

\section{METODE PENELITIAN}

Jenis penelitian ini merupakan penelitian analitik observasi desain cross sectional Penelitian ini dilaksanakan pada bulan Desember 2019 sampai dengan bulan Juni 2020. Penelitian ini dilakukan di RSUD M.Natsir. Populasi pada penelitian ini adalah semua pasien yang datang ke laboratorium dengan penderita suspek TB paru selama tahun 2019. Sampel dalam penelitian ini adalah pasien suspek TB Paru sebanyak 190 sampel. Data dianalisis dengan menggunakan uji statistik ChiSquare dengan tingkat kemanaan $\mathrm{P}<0,05$.

\section{HASIL DAN PEMBAHASAN}

Karakteristik umum subjek penelitian dapat dilihat pada tabel 1.

\section{Tabel 1 Karakteristik responden berdasarkan jenis kelamin dan Umur}

\begin{tabular}{lcc}
\hline \multicolumn{1}{c}{ Variabel } & f & $\%$ \\
\hline Jenis Kelamin & & \\
Laki-laki & 97 & 51,1 \\
Perempuan & 93 & 48,9 \\
Umur & & \\
$3-12$ & 3 & 1,6 \\
$13-22$ & 20 & 10,5 \\
$23-32$ & 27 & 14,2 \\
$33-42$ & 27 & 14,2 \\
$43-52$ & 28 & 14,7 \\
$53-62$ & 41 & 21,6 \\
$63-72$ & 29 & 15,3 \\
$73-82$ & 13 & 6,8 \\
$83-92$ & 2 & 1,1 \\
\hline
\end{tabular}

Pada tabel 1 karakteristik umum subjek penelitian berdasarkan jenis kelamin dan umur, pada tabel jenis kelamin laki-laki sebanyak 97 sampel $(51,1 \%)$ dan 
perempuan sebanyak 93 sampel (48,9\%). Laki-laki memiliki frekuensi lebih tinggi menderita TB paru dibandingkan dengan perempuan yang juga dinyatakan pada penelitian Perez Guzman et al, (2003), yang menyatakan sebagian besar pasien TB adalah laki-laki. Hal ini dikarenakan tingkat aktifitas dan pekerjaan. Tingginya angka penderita TB pada rentang umur produktif pada laki-laki diduga ada hubungannya dengan tingkat aktifitas dan pekerjaan sebagai tenaga produktif yang memungkinkan untuk mudah tertular dengan bakteri TB setiap saat dari penderita lain yang BTA positif ataupun BTA negatif.

Karakteristik umum subjek penelitian berdasarkan umur 3-12 tahun berjumlah 3 orang (1,6\%), umur 13-22 tahun berjumlah 22 orang (10.5\%), umur 23-32 tahun berjumlah 27 orang (14,2\%), umur 33-42 tahun berjumlah 27 orang $(14,2 \%)$, umur 43- 52 tahun berjumlah 28 orang $(14,7 \%)$, umur 53-62 tahun berjumlah 41 orang
$(21,6 \%)$, umur $63-72$ tahuun berjumlah 29 orang (15,3\%), umur 73-82 tahun berjumlah 13 orang $(6,8 \%)$, umur 83-92 tahun berjumlah 2 orang (1,1\%). Dan pada umur yang berusia 53-62 tahun berjumlah 41 orang $(21,6 \%)$, besaran angka ini dapat diartikan bahwa pada umumnya pasien suspek Tuberkulosis Paru di RSUD M.Natsir berumur 53-62 tahun. Hal ini sesuai dengan beberapa peneliti lain yang 24 mendapatkan penderita TB Paru yang paling sering dijumpai pada usia produktif. Pada umur 15-50 tahun termasuk orang yang produktif. Orang yang produktif memiliki resiko 5-6 kali untuk mengalami kejadian TB paru, hal ini karena pada kelompok usia produktif setiap orang akan cenderung beraktivitas tinggi, sehingga kemungkinanterpapar bakteri

Mycobacterium tuberkulosis lebih besar, selain itu bakteri tersebut akan aktif kembali dalam tubuh yang cenderung terjadi pada usia produktif.

Tabel 2 Hubungan Hasil Pemeriksaan GeneXpert dengan Basil Tahan Asam (BTA) Metode Ziehl Neelsen

\section{Metode}

GeneXpert

MTB Not Detection

MTB Detection Low

MTB Detection Medium

MTB Detection High

MTB Not Detection

Total
Ziehl Neelsen

P Value

\begin{tabular}{ccccccc} 
Negatif & $\mathbf{1 +}$ & $\mathbf{2 +}$ & $\mathbf{3 +}$ & Total & Negatif & \\
147 & 0 & 0 & 0 & 147 & 147 & \\
0 & 20 & 0 & 0 & 20 & 0 & \\
0 & 0 & 17 & 0 & 17 & 0 & 0,00 \\
0 & 0 & 0 & 6 & 6 & 0 & \\
147 & 0 & 0 & 0 & 147 & 147 & \\
147 & 20 & 17 & 6 & 190 & 147 & \\
\hline
\end{tabular}

dan hasil positif Tiga (3+) sebanyak 6 orang. Hasil pemeriksaan mikroskopis dibaca dengan skala IUALTD (International Union Against Tuberculosis and Lung Disease), sedangkan hasil pemeriksaan GeneXpert dinyatakan dalam MTB not detected, MTB detected very low, MTB detected low, MTB detected medium dan MTB detected high (Cekin et al., 2013)(SURYAWATI et al., 2019).

Hasil uji Chi-Square menunjukkan significance $(0,00)$, dimana pada Uji ChiSquare significance $0,00<0,05$, artinya 
terdapat hubungan hasil pemeriksaan Metode GeneXpert dengan Tingkat Positivitas Basil Tahan Asam (BTA) Metode Ziehl Neelsen pada Penderita Suspek TB Paru. Sejalan dengan penelitian Eka
(2016), dari hasil uji diagnostik dengan geneXpert untuk mendiagnosis TB paru BTA negatif didapatkan sensitivitas $83.33 \%$, spesifitas $95.46 \%$ dan akurasi $90 \%$.

\section{BTA_GENEXPERT}

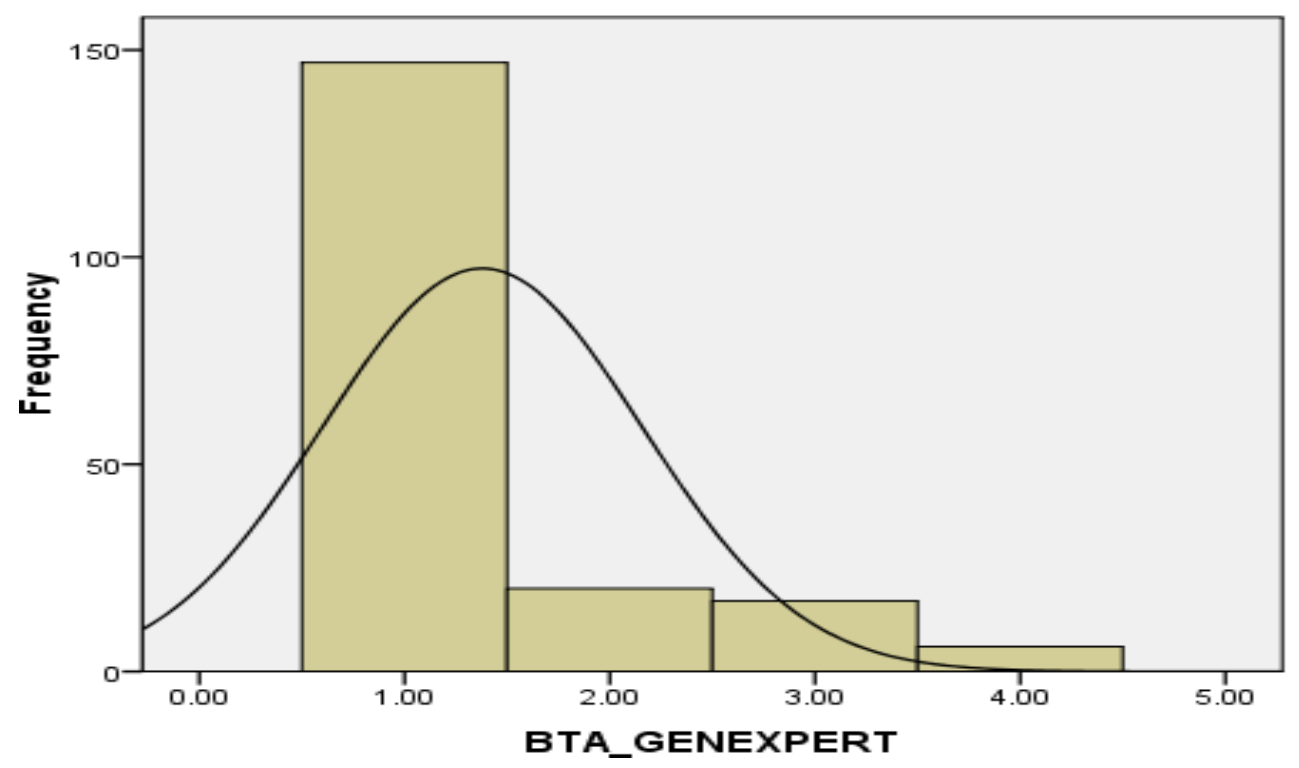

Mean $=1.38$
Std. Dev. $=0.779$
$N=190$

Grafik 1. BTA GeneXpert

Berdasarkan grafik 1 dapat dilihat bahwa frequensi Basil Tahan Asam (BTA) GeneXpert, pada kurva 1,00 didapatkan hasil 147 sampel negatif. Pada kurva 2,00 didapatkan hasil 20 sampel posotif 1 , pada kurva 3,00 didapatkan hasil 17 sampel positif 2, pada kurva 4,00 didapatkan hasil 6 sampel positif dengan mean 1,38 dan Standar Deviasi 0,779 dari 190 sampel.

Berdasarakan grafik 2 dapat dilihat frequensi Basil Tahan Asam (BTA) metode Ziehl Neelsen, pada kurva 1,00 didapatkan hasil 147 sampel negatif. Pada kurva 2,00 didapatkan hasil 20 sampel posotif 1, pada kurva 3,00 didapatkan hasil 17 sampel positif 2, pada kurva 4,00 didapatkan hasil 6 sampel positif 3 . Dengan mean 1,38 dan Standar Deviasi 0,779 dari 190 sampel.

Hasil penelitian ini menunjukkan bahwa pemeriksaan GeneXpert dan Basil Tahan Asam (BTA) metode Ziehl Neelsen samasama sensitif karena didapatkan data yang sama dari hasil pemeriksaan GeneXpert dengan Basil Tahan Asam (BTA) metode Ziehl Neelsen. Berdasarkan skala IUATLD (International Union Against Tuberculosis and Lung Disease) hasil negatif pada pemeriksaan mikroskopis jika tidak ditemukan BTA dalam 100 lapang pandang. Perbedaan hasil secara mikroskopis dan GeneXpert terjadi karena pada pemeriksaan mikroskopis dalam sputum harus terkandung minimal 5000 bakteri/ml sputum untuk mendapatkan hasil positif, banyaknya jaringan lendir akan memperbesar volume sampel sehingga memperkecil kemungkinan untuk dapat mengambil sampel yang mengandung bakteri Mycobacterium tuberkulosis, kekurangan lainnya dalam hal interpretasi hasil laboratorium, dimana para klinisi sering mengalami kesulitan untuk menentukan diagnosis tuberkulosis pada pasien yang memiliki hasil pemeriksaan mikroskopis scanty (Groenewald et al., 2014). Sedangkan pada pemeriksaan GeneXpert 
dengan metode deteksi molekuler berbasis nested real-time PCR mampu mendeteksi DNA MTB kompleks secara kualitatif (Pandey et al., 2017), sehingga memungkinkan pada pemeriksaan mikroskopis BTA tidak ditemukan tetapi dapat terdeteksi pada pemeriksaan GeneXpert, karena GeneXpert mampu mendeteksi MTB dalam bentuk hancur sekalipun. Perkembangan teknologi saat ini yang mampu mendeteksi TB dengan cepat dan akurat adalah dengan pemeriksaan
GeneXpert (Dharan et al., 2015)(Utami et al., 2021). GeneXpert MTB/RIF adalah suatu alat uji yang menggunakan cartridge berdasarkan Nucleic Acid Amplification Test (NAAT), secara automatis untuk mendeteksi kasus TB dan resistensi rifampisin. Alat ini cocok untuk negara endemis, dan dapat dilakukan walaupun sampel sputum hanya $1 \mathrm{ml}$ (Pandey et al., 2017)(Ibrahim et al., 2014)(Rahmadea Utami et al., 2020).

\section{BTA_ZIEHLNELSEEN}

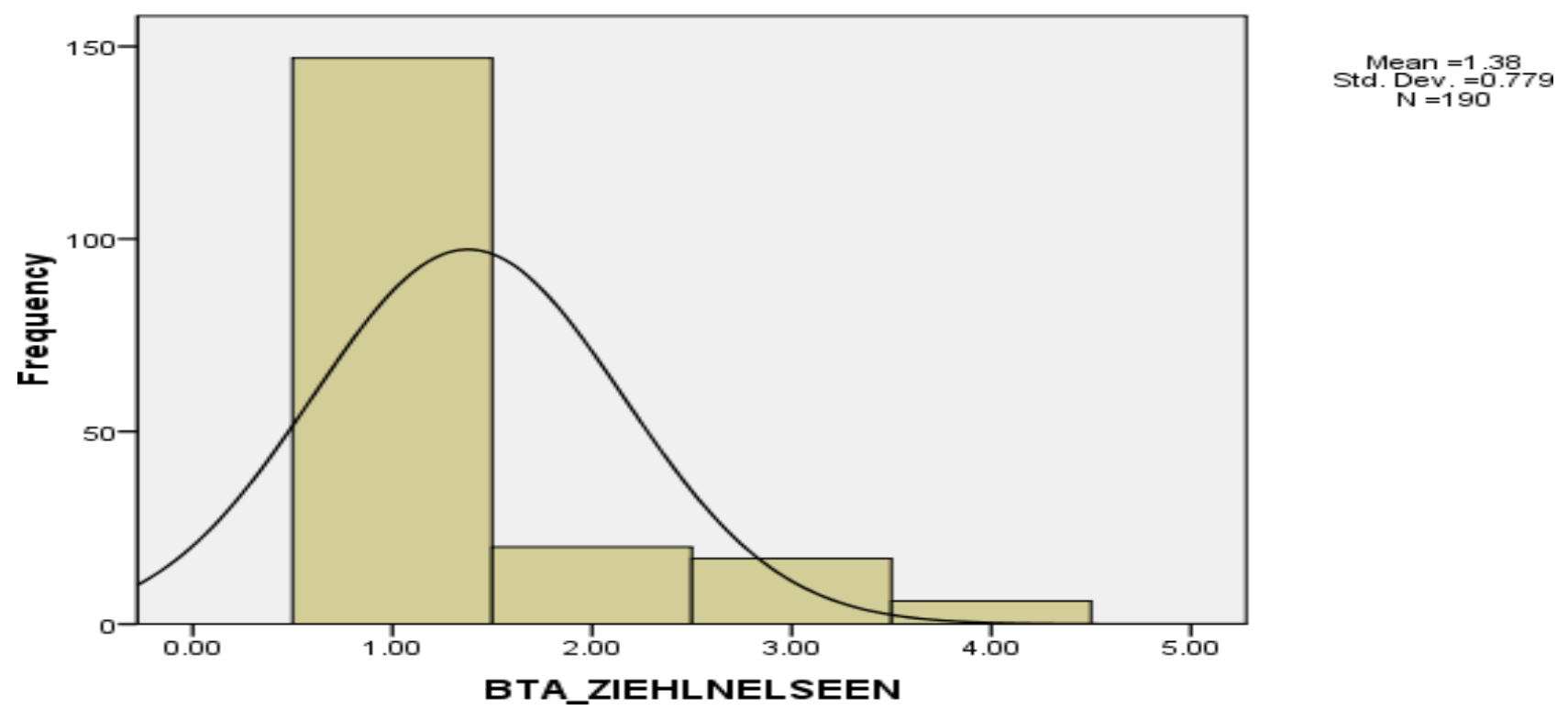

Grafik 2. BTA Ziehl Neelsen

Berdasarkan hasil dan pembahasan terhadap hubungan hasil pemeriksaan GeneXpert dengan tingkat positivitas pemeriksaan Basil Tahan Asam (BTA) metode Ziehl Neelsen pada penderita suspek TB Paru sebanyak 190 sampel, pada pemeriksaan GeneXpert dapat dideteksi sampel bakteri yang telah mati, dimana Efektivitas RT-PCR GeneXpert lebih sensitif dibanding pemeriksaan dengan metode mikroskopik karena pada metode mikroskopik Basil Tahan Asam (BTA) harus diperiksa dalam keadaan hidup dalam waktu kurang dari dua jam agar warna terlihat jelas. Sedangkan menggunakan metode GeneXpert Mycobacterium tuberkulosis yang sudah mati tetap terdeteksi karena yang dideteksi adalah DNA dari bakteri tersebut (Nugraha et al., 2018). Pada bakteri Mycobacterium tuberkulosis yang telah mati pada metode Ziehl Neelsen, bakteri akan mati setelah dipanaskan diatas suhu $60^{\circ}$ Celsius pada pewarnaan Ziehl Neelsen, Metode mikroskopik ini mendeteksi adanya BTA secara jelas dengan menggunakan mikroskop pewarnaan Ziehl Neelsen yang memberikan latar belakang berwarna biru terang dan basi Itampak jelas berwarna merah. Deteksi MTB kompleks dipengaruhi oleh jumlah mikroorganisme dalam spesimen dan hasil yang terbaca sangat dipengaruhi oleh cara pengumpulan, pengolahan dan penyimpanan spesimen (Boehme et al., 2011)(khariri, 2020)(Misnarliah1, 2020). 
Pada penelitian ini didapatkan Hubungan yang signifikan antara metode GeneXpert dengan Basil tahan Asam (BTA) metode Ziehl Neelsen. Dapat disimpulkan Metode RT-PCR GeneXpert mempunyai nilai sensitivitas, spesifisitas, nilai prediksi positif, nilai prediksi negatif dan akurasi yang tinggi untuk menegakkan diagnosis tuberkulosis paru terhadap BTA negatif.

\section{KESIMPULAN}

Dari hasil penelitian hubungan hasil pemeriksaan metode GeneXpert dengan tingkat positivitas metode Ziehl Neelsen pada penderita suspek TB paru, didapatkan kesimpulan sebagai berikut: Hasil pemeriksaan GeneXpert pada penderita Suspek TB Paru didapatkan hasil pada metode GeneXpert, MTB Not Detection sebanyak 147 orang, MTB Detection Low sebanyak 20 orang, MTB Detection Medium sebanyak 17 orang, MTB Detection High sebanyak 6 orang, Tingkat Positivitas hasil pemeriksaan Basil tahan Asam (BTA) Metode Ziehl Nelseen metode Ziehl Nelseen didapatkan hasil negatif sebanyak 147 orang, hasil positif Satu (1+) sebanyak 20 orang, hasil positif Dua (2+) sebanyak 17 orang dan hasil positif Tiga (3+) sebanyak 6 orang,Terdapat hubungan yang bermakna antara metode GeneXpert dengan Basil Tahan Asam (BTA) metode Ziehl Nelseen yang mana nilai significance $<0,05$ yaitu 0,00 .

\section{REFERENSI}

Boehme, C. C., Nicol, M. P., Nabeta, P. Michael, J. S., Gotuzzo, E., Tahirli, R., Gler, M. T., Blakemore, R., Worodria, W., Gray, C., Huang, L., Caceres, T., Mehdiyev, R., Raymond, L., Whitelaw, A., Sagadevan, K., Alexander, H., Albert, H., Cobelens, F., ... Perkins, M. D. (2011). Feasibility, diagnostic accuracy, and effectiveness of decentralised use of the Xpert MTB/RIF test for diagnosis of tuberculosis and multidrug resistance: A multicentre implementation study. The Lancet,
377(9776), 1495-1505. https://doi.org/10.1016/S0140-

6736(11)60438-8

Cekin, Y., Daloğlu, A. E., Öğünç, D., Baysan, B. Ö., Dağlar, D., Inan, D., Mutlu, D., Öngüt, Gö., \& O̧olak, D. (2013). Evaluation of vancomycin resistance 3 multiplexed pcr assay for detection of vancomycin-resistant enterococci from rectal swabs. Annals of Laboratory Medicine, 33(5), 326330.

https://doi.org/10.3343/alm.2013.33.5. 326

Dharan, N. J., Amisano, D., Mboowa, G., Ssengooba, W., Blakemore, R., Kubiak, R. W., Armstrong, D. T., Jones, M., Manabe, Y. C., Joloba, M. L., Ellner, J. J., Dorman, S. E., \& Alland, D. (2015). Improving the sensitivity of the Xpert MTB/RIF assay on sputum pellets by decreasing the amount of added sample reagent: A laboratory and clinical evaluation. Journal of Clinical Microbiology, 53(4), 1258-1263. https://doi.org/10.1128/JCM.03619-14

Groenewald, W., Baird, M. S., Verschoor, J. A., Minnikin, D. E., \& Croft, A. K. (2014). Differential spontaneous folding of mycolic acids from Mycobacterium tuberculosis. Chemistry and Physics of Lipids, 180, 15-22.

https://doi.org/10.1016/j.chemphyslip. 2013.12.004

Ibrahim, F., Elliya, R., \& Pribadi, T. (2014). Hubungan Dukungan Keluarga Dengan Kepatuhan Minum Obat TB Paru Pada Penderita TB Paru Di Wilayah Kerja Puskesmas Panaragan Jaya Kabupaten Tulang Bawang Barat Tahun 2013. Jurnal Kesehatan Holistik, 8(2), 71-75.

khariri. (2020). Prosiding Seminar Nasional SMIPT 2020 Pemeriksaan Basil Tahan Asam ( BTA ) pada Sputum dengan Pewarnaan Ziehl Neelsen ( ZN ) Sebagai Metode Populer untuk Penegakkan Diagnosis TB Paru. 3(1), 132-139.

Kurniawan, E., Raveinal, R., Fauzar, F., \& Arsyad, Z. (2016). Nilai Diagnostik Metode "Real Time" PCR GeneXpert pada TB Paru BTA Negatif. Jurnal 
Kesehatan Andalas, 5(3), 730-738. https://doi.org/10.25077/jka.v5i3.609

Misnarliah1, M. (2020). Pengaruh penundaan pewarnaan preparat bakteri tahan asam metode ziehl neelsen terhadap hasil pemeriksaan mikroskopik. Jurnal Teknosains Kodepena, 58-63.

Muin, W. O. N. A., Kalma, Artati, \& Rafika. (2020). Pengaruh Lama Penyimpanan Dahak Pagi pada Suhu Kamar Terhadap Jumlah Bakteri Tahan Asam (BTA). Jurnal Media Analis Kesehatan, 11(2), 104-111.

Nugraha, T., Saptawati, L., Eka, K., \& Larasati, R. (2018). Evaluasi Metode GeneXpert MTB / RIF dengan Sampel Raw Sputum untuk Mendeteksi Tuberkulosis Paru Evaluation of GeneXpert MTB / RIF Method Using Raw Sputum Samples for Detecting Pulmonary Tuberculosis. 2(1), 7-10.

Pandey, P., Pant, N. D., Rijal, K. R., Shrestha, B., Kattel, S., Banjara, M. R., Maharjan, B., \& Kc, R. (2017). Diagnostic Accuracy of GeneXpert MTB / RIF Assay in Comparison to Conventional Drug Susceptibility Testing Method for the Diagnosis of Multidrug-Resistant Tuberculosis. 813.

https://doi.org/10.1371/journal.pone.0 169798

Rahmadea Utami, P., Chairani, \& Yudha, H. (2020). Combination Test Of Chinese Leaf Extract (Leucaena leucocephala folium) And Aloe Vera Inhibiting Growth Escherichia coli. Indonesian Journal of Medical Laboratory Science and Technology,
2(2), $60-67$. https://doi.org/10.33086/ijmlst.v2i2.15 77

Saeed, M., Ahmad, M., Iram, S., Riaz, S., Akhtar, M., \& Aslam, M. (2017). GeneXpert technology: A breakthrough for the diagnosis of tuberculous pericarditis and pleuritis in less than 2 hours. Saudi Medical Journal, 38(7), 699-705. https://doi.org/10.15537/smj.2017.7.1 7694

SURYAWATI, B., SAPTAWATI, L., PUTRI, A. F., \& APHRIDASARI, J. (2019). Sensitivitas Metode Pemeriksaan Mikroskopis Fluorokrom dan ZiehlNeelsen untuk Deteksi Mycobacterium tuberculosis pada Sputum. Smart Medical Journal, 1(2), 56.

https://doi.org/10.13057/smj.v1i2.287 04

Susanti, D. (2013). Pemeriksaan Basil Tahan Asam (BTA) Pada sputum penderita batuk $\geq 2$ minggu di poliklinik penyakit dalam blu rsup. prof. dr. r.d kandou manado. E-CliniC, 1(1), 1-5. https://doi.org/10.35790/ecl.1.1.2013. 4037

Utami, P. R., Indrayati, S., \& Hayatang, N. (2021). Ability of Ethanol Extract from Ajwa and Sukkari Dates (Phoenix dactylifera L.) in Inhibiting the Growth of Methicillin-Resistant Staphylococcus aureus (MRSA). Indonesian Journal of Medical Laboratory Science and Technology, 3(1), 1-8. https://doi.org/10.33086/ijmlst.v3i1.18 48 